\title{
UJI AKTIVITAS ANTIOKSIDAN TERONG BELANDA (Solanum betaceum Cav.) DENGAN METODE FRAP
}

\author{
Sukmawati Syarif, Rachmat Kosman, Nurul Inayah \\ Fakultas Farmasi Universitas Muslim Indonesia \\ Email : sukmasyarif@gmail.com.
}

\begin{abstract}
Test Antioxidant Activity of Dutch eggplant (Solanum betaceum Cav.) with FRAP method. This study aims to measure and determine the antioxidant activity Dutch eggplant (Solanum betceum Cav.) with FRAP method. Dutch eggplant was analyzed qualitatively by using the metod FRAP with FRAP reagent. Quantitatively mix with the sample solution was analyzed by FRAP method Uv-Vis spectrophotometer at a wavelength $596 \mathrm{~nm}$. By using trolox as a reference standard. The results obtained in this research that Dutch eggplant has antioxidant activity with an total value of antioxidant activity, 0,9353 $\mu \mathrm{mol}$ Trolox/gr sample.
\end{abstract}

Keywords : Dutch eggplant, Antioxidant Activity, FRAP, Trolox, UV-VIS Spectrophotometer.

\section{PENDAHULUAN}

Makanan yang kita konsumsi dimasa sekarang sudah banyak mengandung bahan-bahan tambahan, yang apabila dikonsumsi dengan kadar yang berlebihan akan berdampak buruk bagi tubuh. Akibatnya berbagai penyakit bermunculan menyerang tubuh kita (Stevi G. dkk. 2012).

Hal itu semua tidak luput dari adanya radikal bebas. Radikal bebas adalah atom atau gugus yang memiliki satu atau lebih elektron tidak berpasangan. Radikal bebas juga dijumpai pada lingkungan, beberapa logam (contohnya besi dan tembaga), asap rokok, obat, makanan dalam kemasan, bahan aditif, dan lain-lain (Stevi G. dkk. 2012).

Radikal bebas ini dapat dihindari dengan antioksidan yang dihasilkan oleh tubuh. Akan tetapi, antioksidan yang terdapat dalam tubuh harus terdapat dalam jumlah yang memadai. Pada keadaan patologik diantaranya akibat terbentuknya radikal bebas dalam jumlah berlebihan, enzim-enzim yang berfungsi sebagai antioksidan endogen dapat menurun aktivitasnya. Oleh karena itu, jika terjadi peningkatan radikal bebas dalam tubuh, dibutuhkan antioksidan eksogen (yang berasal dari bahan pangan yang 
dikonsumsi) dalam jumlah yang lebih banyak untuk mengeliminir dan menetralisir efek radikal bebas (Astuti,2008).

Buah, sayur, dan biji-bijian merupakan sumber antioksidan alami yang telah diketahui berpotensi mengurangi resiko penyakit kronis, termasuk penyakit hati dan beberapa jenis kanker. Antioksidan yang terkandung dalam tumbuhan berupa vitamin $C$, vitamin $E$, karoten dan golongan fenol (Puji, 2007).

Keanekaragaman

hayati

Indonesia sangat berpotensi dalam penemuan senyawa baru sebagai antioksidan. Beberapa penelitian menunjukan bahwa beberapa tumbuhan terbukti bermanfaat melindungi tubuh manusia dari bahaya radikal bebas, karena adanya antioksidan yang terdapat dalam tumbuhan tersebut. Secara alami, tumbuhan yang mengandung antioksidan tersebar pada berbagai bagian tumbuhan seperti akar, batang, kulit, ranting, daun, buah, bunga dan biji (Selawa,2013).

Terong belanda adalah buah yang mempunyai kandungan nutrisi yang sangat baik, berisi beberapa kandungan vitamin yang sangat penting serta kaya akan besi dan pottasium, kandungan sodium yang rendah dan berisi kurang dari 40 kalori (kurang lebih $160 \mathrm{~kJ}$ ). Oleh karena kelengkapan dari kandungan gizi pada tamarillo, maka di Amerika Serikat buah terong belanda terkenal sebagai buah yang mengandung rendah kalori, sumber serat, bebas lemak (jenis reds) atau rendah lemak (jenis golden), bebas kolesterol dan sodium dan sumber vitamin $C$ dan $E$ yang sempurna (Kumalaningsih, 2006).

Berbagai bukti ilmiah menunjukkan bahwa resiko penyakit kronis akibat senyawa radikal bebas dapat dikurangi dengan memanfaatkan peran senyawa antioksidan seperti vitamin C, E, A, karoten, asam-asam fenol, polifenol dan flavonoid. Karakter utama senyawa antioksidan adalah kemampuannya untuk menangkap dan menstabilkan radikal bebas (Prakash, 2001).

Metode yang digunakan pada penentuan aktivitas antioksidan terong belanda (Solanum betaceum Cav.) pada penelitian ini adalah metode FRAP. Vargia (2002) mengemukakan bahwa metode FRAP adalah metode yang digunakan untuk menguji antioksidan dalam tumbuh-tumbuhan. Kelebihan metode FRAP ini yaitu metodenya yang murah, cepat, dan reagen yang digunakan cukup sederhana serta tidak menggunakan 
alat khusus untuk menghitung total antioksidan.

Berdasarkan uraian diatas, maka akan dilakukan penelitian yang bertujuan untuk menguji aktivitas antioksidan terong belanda (Solanum betaceum Cav.) dengan metode FRAP (Ferric reducing antioxidant power).

\section{METODE PENELITIAN}

\section{Waktu dan tempat penelitian}

Penelitian ini dilakukan pada bulan Januari sampai Juni 2014. Dilaksanakan di Laboratorium Kimia Fakultas Farmasi Universitas Muslim Indonesia Makassar.

\section{Alat dan bahan}

Alat yang digunakan yaitu alat sentrifuge (Onomed), batang pengaduk, botol semprot, corong (Herma), cawan porselen, gelas kimia (Pyrex), gelas ukur (Pyrex), juicer, labu ukur (Pyrex), mikropipet (Dragon lab), penjepit tabung, pipet skala (Pyrex), pipet tetes, pipet volume (Pyrex), rak tabung, sendok tanduk, spektrofotometer UV-Vis (Apel), tabung reaksi (Pyrex), tabung sentrifuge (Pyrex), timbangan analitik (Acis $A D-600 \mathrm{H}$ ), dan vortex.

Bahan yang digunakan adalah akuades, aluminium foil, asam klorida 40 $\mathrm{mmol} / \mathrm{L} \quad$ (Merck), asam trikloroasetat $10 \%$, besi (III) klorida, dapar asetat $\mathrm{pH}$ 3,6, etanol p.a (Merck), etanol 96\% (Merck), kertas saring, terong belanda (Solanum betaceum Cav.), TPTZ (Merck), troloks (Merck).

\section{Analisis Aktivitas Antioksidan Metode FRAP \\ Pengolahan Sampel}

Terong belanda yang diperoleh, terlebih dahulu di kupas kulitnya kemudian dibersihkan, lalu daging terong belanda di potong kecil-kecil, kemudian di juicer dan di pipet sebanyak $5 \mathrm{ml}$ ditambahkan $1 \mathrm{~mL}$ asam trikloroasetat $10 \%$, kemudian disentrifuge dalam $3000 \mathrm{rpm}$ selama 10 menit. Supernatan dipipet $1 \mathrm{ml}$ kemudian diencerkan dengan $5 \mathrm{ml}$ etanol p.a (1:5).

\section{Penyiapan Larutan}

\section{Larutan Dapar Asetat pH 3,6}

Pembuatan dapar asetat dengan $\mathrm{pH}$ 3,6 dibuat dengan melarutkan $0,775 \mathrm{~g}$ natrium asetat $\left(\mathrm{CH}_{3} \mathrm{COONa}\right)$ kedalam $4 \mathrm{~mL}$ asam asetat pekat dan dilarutkan dengan akuades hingga tepat $250 \mathrm{~mL}$ dalam labu takar.

\section{Larutan $\mathrm{FeCl}_{3} 20 \mathrm{mmol} / \mathrm{L}$}

Sebanyak $\quad 54 \quad \mathrm{mg}$ $\mathrm{FeCl}_{3}$ dilarutkan dengan akuades dalam labu takar hingga tepat 10 $\mathrm{mL}$. 
3. Larutan $\mathrm{HCl} 40 \mathrm{mmol} / \mathrm{L}$

Sebanyak 0,33 $\mathrm{mL} \mathrm{HCl}$ pekat dilarutkan dengan akuades dalam labu takar hingga $100 \mathrm{~mL}$ akuades.

4. Larutan TPTZ (2,4,6-tripyridilstriazine) $10 \mathrm{mmol} / \mathrm{mL}$

Sebanyak $25 \mathrm{mg}$ TPTZ dilarutkan dalam $8,33 \mathrm{~mL} \mathrm{HCl} 40$ $\mathrm{mmol} / \mathrm{L}$.

5. Larutan asam trikloroasetat $10 \%$

Sebanyak 10 gram $\mathrm{CCl}_{3} \cdot \mathrm{CO}_{2} \mathrm{Hdilarutkan}$ dengan akuades dalam labu takar hingga tepat $100 \mathrm{~mL}$.

\section{Reagen FRAP}

Reagen FRAP dibuat dengan cara mencampurkan $25 \mathrm{~mL}$ buffer asetat, 2,5 mL larutan TPTZ dan 2,5 larutan $\quad \mathrm{FeCl}_{3} \cdot 6 \mathrm{H}_{2} \mathrm{O}$, lalu ditambahkan akuades hingga tepat $100 \mathrm{~mL}$ dalam labu takar.

\section{Larutan Standar Trolox}

Larutan stok $600 \mu$ Mdibuat dengan melarutkan $15 \mathrm{mg}$ trolox dilarutkan dengan etanol p.a. Lalu di encerkan hingga batas labu ukur $100 \mathrm{~mL}$.

Analisis Kualitatif Aktivitas

\section{Antioksidan dengan Metode FRAP}

Larutan sampel dipipet sebanyak $1 \mathrm{~mL}$ menggunakan pipet mikro dan masukkan ke dalam tabung reaksi, kemudian tambahkan $3 \mathrm{~mL}$ reagen $\quad$ FRAP. Campuran dihomogenkan dan diinkubasi pada suhu $37^{\circ} \mathrm{C}$ selama 30 menit. Diamati perubahan warna larutan yang terjadi. Apabila larutan yang tidak berwarna berubah menjadi warna biru, maka sampel memiliki aktivitas sebagai antioksidan.

\section{Analisis Kuantitatif Antioksidan dengan Metode FRAP}

a. Penentuan Panjang Gelombang Serapan Maksimum ( $x$ maks) Panjang gelombang maksimum diperoleh melalui pengukuran absorbansi dari standar Trolox dengan konsentrasi yang paling tinggi $(600 \mu \mathrm{M})$. Dari larutan tersebut diambil sebanyak $1 \mathrm{~mL}$ kemudian ditambahkan reagen FRAP sebanyak $3 \mathrm{~mL}$, lalu dibaca pada setiap panjang gelombang dalam kisaran 580-610 nm dengan menggunakan spektrofotometer UV-Vis.

b. Penentuan Absorbansi Sampel (merujuk pada Selawa dkk (2013) dengan beberapa modifikasi)

Sebanyak $1 \mathrm{~mL}$ masingmasing sampel dimasukkan ke dalam tabung reaksi, kemudian ditambahkan sebanyak $3 \mathrm{~mL}$ reagen FRAP ke dalam tabung reaksi. Selanjutnya campuran 
tersebut diinkubasi pada suhu $37^{\circ} \mathrm{C}$ selama 30 menit. Setelah itu, semua larutan uji dibaca serapannya pada $\lambda$ maks $596 \mathrm{~nm}$ dengan spektrofotometer UV-Vis.

c. Penentuan Absorbansi Troloks

Larutan stok $600 \mu \mathrm{M}$ yang telah dibuat kemudian diambil masing-masing sebanyak $0,83 \mathrm{~mL}$; 1,6 mL; 2,5 mL; 3,3 mL; 4,1 mL; 5 $\mathrm{mL}$ dan ditempatkan pada labu ukur berbeda dan diencerkan dengan etanol p.a hingga $5 \mathrm{~mL}$ dan dihomogenkan. Konsentrasi larutan standar troloks yang terbentuk berturut-turut $100 \mu \mathrm{M}, 200 \mu \mathrm{M}, 300$ $\mu \mathrm{M}, 400 \mu \mathrm{M}, 500 \mu \mathrm{M}, 600 \mu \mathrm{M}$.
Dilakukan hal yang sama seperti pada sampel dengan penambahan reagen yang digunakan dalam metode FRAP.

\section{Perhitungan nilai TEAC}

Perhitungan yang digunakan dalam menentukan aktivitas antioksidan adalah nilai TEAC (trolox equivalent antioxidant capacity) berdasarkan data absorbansi dan konsentrasi dari persamaan $y=a+$ bx, dapat dihitung nilai kapasitas antioksidan dengan menggunakan rumus :

TEAC $=\frac{V \text { Sampel }(m L) x[\text { sampel }] x f p}{\text { Bat }}$

\section{HASIL PENELITIAN}

Tabel 1. Data analisis kualitatif aktivitas antioksidan sampel jus terong belanda dengan metode FRAP

Larutan Sebelum penambahan reagen FRAP

\begin{tabular}{lll}
\hline Sampel & Tidak berwarna & Biru \\
\hline
\end{tabular}

\section{Keterangan :}

$(+) \quad=$ ada aktivitas antioksidan

FRAP = tidak berwarna $\longrightarrow$ biru

Tabel 2. Data analisis kuantitatif antioksidan terong belanda dengan metode FRAP

\begin{tabular}{ccc}
\hline Larutan & $\begin{array}{c}\text { Kapasitas } \\
\text { Antioksidan metode FRAP }(\boldsymbol{\mu M} \\
\text { TR/ g sampel) }\end{array}$ & $\begin{array}{c}\text { Rata-rata Kapasitas } \\
\text { Antioksidan metode FRAP } \\
(\mu \mathrm{M} \text { TR/ g sampel) }\end{array}$ \\
\hline Rep I & 0,9059 & \\
Rep II & 0,9381 & 0,9353 \\
Rep III & 0,9621 & \\
\hline
\end{tabular}




\section{PEMBAHASAN}

Terong Belanda memiliki bentuk yang menyerupai telur, hanya saja diujungnya terlihat lebih meruncing. Terong jenis ini memiliki warna yang cerah, yaitu merah kekuningan dan begitu juga dengan dagingnya. Sehingga jika sekilas di perhatikan sayuran atau buah ini hampir menyerupai buah tomat, akan tetapi jika dibelah, maka bagian tengah atau bagian biji terong ini berwarna ungu kehitaman.

Terong Belanda lebih banyak dikonsumsi sebagai buah. Buah yang terasa asam ini semakin terasa nikmat setelah diolah menjadi minuman segar kaya manfaat seperti jus. Jenis terong Belanda ini memang cukup berbeda dengan jenis terong-terong lainnya, sehingga terong belanda ini merupakan salah satu tumbuhan yang menarik untuk diteliti sebagai komponen aktif antioksidan.

Terong belanda merupakan buah yang sangat berpotensi sebagai antioksidan alami, dimana buah ini mengandung vitamin $C$, vitamin $A$, serat yang tinggi, mineral, dan flavonoid yang merupakan sumber antioksidan yang sangat kuat.

Metode FRAP adalah metode yang dapat digunakan untuk menguji antioksidan dalam tumbuh-tumbuhan.
Kelebihan metode FRAP ini yaitu metodenya yang murah, cepat dan reagen yang digunakan cukup sederhana serta tidak menggunakan alat khusus untuk menghitung total antioksidan. Metode FRAP digunakan untuk mengukur kemampuan antioksidan dalam mereduksi $\mathrm{Fe}^{3+}$ menjadi $\mathrm{Fe}^{2+}$ dengan peningkatan nilai absorbansi menunjukkan besarnya aktivitas antioksidan dari sampel yang diuji. Penentuan kapasitas antioksidan kedua metode dilakukan dengan menghitung kurva baku troloks.

Penentuan nilai aktivitas antioksidan dilakukan dengan mencampurkan reagen FRAP dengan sampel jus terong belanda. Dalam reagen FRAP terdapat campuran TPTZ, $\mathrm{FeCl}_{3}$ dan buffer asetat. Aktivitas antioksidan dapat dilihat dari kemampuan-nya mereduksi $\mathrm{Fe}^{3+}$ TPTZ yang tidak berwarna menjadi $\mathrm{Fe}^{2+}$ yang berwarna biru. Hal ini dapat dilihat pada pembanding dan sampel yang berkhasiat sebagai antioksidan seperti pada tabel 1 .

Menurut Ou et al., (2002) dalam Istiningrum (2013) senyawa $\mathrm{Fe}^{3+}-\mathrm{TPTZ}$ mewakili senyawa oksidator yang mungkin terdapat dalam tubuh dan dapat merusak sel-sel tubuh, sedangkan sampel mengandung antioksidan yang kemudian dapat 
mereduksi senyawa $\mathrm{Fe}^{3+}-\mathrm{TPTZ}$ menjadi $\mathrm{Fe}^{2+}-\mathrm{TPTZ}$ sehingga senyawa $\mathrm{Fe}^{3+}-$ TPTZ tidak akan melakukan reaksi yang merusak sel-sel tubuh. Semakin banyak konsentrasi $\mathrm{Fe}^{3+}$-TPTZ yang direduksi oleh sampel menjadi $\mathrm{Fe}^{2+}$ TPTZ, maka aktivitas antioksidan dari sampel juga semakin besar.

Persamaan reaksi kurva baku troloks ditunjukkan pada gambar 1, yaitu $y=0.001 x-0.122$ dengan nilai $r$ $=0.995$

Penambahan $\mathrm{FeCl}_{3}$ dalam reagen yaitu untuk membentuk senyawa kompleks $\mathrm{Fe}^{3+}$ dan memperlambat reaksi reduksi $\mathrm{Fe}^{3+}$ menjadi $\mathrm{Fe}^{2+}$ yang terjadi sangat cepat oleh pengaruh cahaya. Sedangkan penambahan buffer asetat adalah karena buffer ini memiliki $\mathrm{pH}$ efektif dari 3,6-5,6 (Gholib, 2007). Dimana telah diketahui bahwa kompleks ini stabil pada $\mathrm{pH}$ asam, maka digunakan $\mathrm{pH} \quad 3.6$ dalam penelitian ini. Penggunaan $\mathrm{pH}$ rendah dimaksudkan untuk memudahkan proses reduksi $\mathrm{Fe}^{3+}$.

Hasil regresi dari konsentrasi $(\mathrm{x})$ dengan nilai absorbansi (y) standar troloks di peroleh persamaan yaitu $y=0.001 x-0.122$ dengan nilai $r=0.995$ dan absorbansi sampel di masukkan ke persamaan tersebut. sampel jus terong belanda diperoleh data absorbansi replikasi I 0,497, replikasi II 0,514 , replikasi III 0,536. Selanjutnya dari data absorbansi yang diperoleh, dapat dilihat aktivitas antioksidannya dengan menggunakan persamaan trolox equivalent antioxidant capacity (TEAC). Dan hasil pengukuran secara kuantitatif didapatkan kapasitas antioksidan yang ekuivalen dengan troloks yaitu untuk replikasi I 0,9059 $\mu \mathrm{mol} \mathrm{TR} / \mathrm{gr}$ sampel, replikasi II 0,9381 $\mu \mathrm{mol}$ TR/gr sampel, replikasi III 0,9621 $\mu \mathrm{mol} \mathrm{TR} / \mathrm{gr}$ sampel, dengan nilai ratarata aktivitas antioksidan sebesar 0,9353 $\mu \mathrm{mol}$ TR/gr sampel.

Pada penelitian ini digunakan pembanding troloks karena troloks merupakan antioksidan sintetik. Secara stuktur troloks serupa dengan a-tokoferol. mempunyai aktivitas antioksidan yang lebih tinggi dibandingkan a-tokoferol, BHA, serta $\mathrm{BHT}$. Troloks sering dipergunakan sebagai standar dalam pengukuran antioksidan. Koefisien TEAC (troloks equivalent antioxidant capacity) adalah konsentrasi troloks yang memiliki kapasitas antioksidan yang ekuivalen dengan sampel yang dianalisis. Kapasitas antioksidan dari setiap metode dinyatakan dalam $\mu \mathrm{mol}$ troloks/g sampel (Widyastuti, 2010).

Penentuan aktivitas antioksidan yang dilakukan dengan metode FRAP 
memiliki kapasitas antioksidan yang dinyatakan ekuivalen dengan troloks (Tabel 2).

Hasil penelitian ini menunjukkan bahwa total antioksidan pada sampel terong belanda dengan menggunakan metode FRAP menunjukkan adanya aktivitas antioksidan. Terbentuknya warna biru menyebabkan kenaikan pada nilai absorbansi sampel. Makin biru warna yang terbentuk pada sampel, maka makin tinggi nilai absorbansinya.

\section{KESIMPULAN}

Berdasarkan hasil penelitian yang talah dilakukan, maka dapat disimpulkan bahwa sampel terong belanda (Solanum betaceum Cav.) memiliki aktivitas antioksidan yang diukur dengan metode FRAP. Dimana terong belanda yang diteliti, memiliki kapasitas antioksidan sebesar 0,9353 $\mu \mathrm{mol}$ troloks / gr sampel.

\section{DAFTAR PUSTAKA}

Astuti, Susi. 2008. Isoflavon Kedelai dan Potensinya Sebagai Penangkap Radikal Bebas. Jurnal Teknologi Industri dan Hasil Pertanian. 2(13):126.

Gholib, G., Rohman, A. 2007. Kimia Farmasi: Analisis. Pustaka Pelajar. Yogyakarta.

Istiningrum, Reni. 2013. Analysis total antioxsidant capacity on ingredients of lotek menu by ferric reducing antioxsidant power assay. Eksakta. Vol 13 : 40-48

Kumalaningsih, S. 2006. Antioksidan Alami Terong Belanda. Trubus Agrisarana : Jakarta.

Prakash A., 2001. Antioxidant Activity, Medallion Laboratories Analytical Progress.19 (2).

Puji, P.A. 2007. Uji Aktivitas Antioksidan Ekstrak Air dan Ekstrak Metanol Beberapa Varian Buah Kenitu (Chysophyllum cainito.L) dari daerah Jember. FMIPA : Universitas Jember, $13: 45$ 50.

Selawa W., Runtuwene M., Citraningtyas G. 2013. Kandungan Flavonoid dan Kapasitas Antioksidan Total Ekstrak Etanol Daun Binahong (Andredera cordifolia (Ten.) Steenis). Pharmacon Jurnal IImiah Farmasi. Vol. 2, no 01 : 18-22

Stevi G. Dungira.,Dewa G. Katja.,Vanda S. 2012. Aktivitas Antioksidan Ekstrak Fenolik Dari Buah Manggis (Garsinia mongostana. L). Jurnal MIPA : UNSTRAT Manado. 1(1) 11-15

Widyastuti, Niken. 2010. Pengukuran Aktivitas Antioksidan dengan METODE CUPRAC, DPPH, DAN FRAP serta korelasinya dengan fenol dan flavanoid pada enam tanaman (skripsi). Institut Pertanian Bogor : Bogor. 